\title{
PENGARUH KEPUASAN PEMAKAI DAN KOMPLEKSITAS SISTEM AKUNTANSI TERHADAP PENGEMBANGAN SISTEM INFORMASI (STUDI DI ORGANISASI PERANGKAT DAERAH PEMERINTAHAN PROVINSI NTB)
}

\author{
Baiq Adriani Ulfa \\ Fakultas Ekonomi dan Bisnis, Universitas Bumigora \\ baiqadrianiulfa@universitasbumigora.ac.id
}

\begin{abstract}
Abstrak
Tujuan penelitian ini adalah untuk mengetahui pengaruh kepuasan pengguna dan kompleksitas sistem akuntansi pada pengembangan sistem informasi pada satuan kerja perangkat daerah (OPD) Barat Provinsi Nusa Tenggara. Penelitian ini tergolong penelitian kuantitatif. Penelitian ini menggunakan data primer yang diperoleh dari penyebaran kuesioner kepada responden. Populasi dalam penelitian ini adalah pegawai pelaksana sistem akuntansil administrasi keuangan di OPD. Dengan menggunakan purposive sampling Teknik penelitian diperoleh 94 responden sebagai sampel penelitian yang terdiri dari bendahara pengeluaran dan bendahara barang pada 48 OPD. Hasil dari Penelitian berdasarkan Partial Least Square (PLS) menunjukkan bahwa kepuasan pengguna mempengaruhi perkembangan sistem informasi, yang akan meningkat produktivitas, efisiensi, dan ketepatan dalam menggunakan sistem. Selain itu, Variabel kompleksitas sistem akuntansi juga mempengaruhi perkembangan sistem informasi, yang akan meningkatkan kinerja dan produksi karyawan informasi yang akurat.
\end{abstract}

Kata Kunci: Kepuasan Pemakai, Kompleksitas Sistem Informasi Akuntansi, Pengembangan Sistem Informasi.

\begin{abstract}
The purpose of this study was to determine the effect of user satisfaction and the complexity of the accounting system on the development of information systems in the West Nusa Tenggara Province Regional Apparatus Work Unit (OPD). This research is classified as a quantitative research. This study uses primary data obtained from distributing questionnaires to respondents. The population in this study were employees of the accounting / financial administration system at OPD. By using purposive sampling. The research technique obtained 94 respondents as the research sample consisting of expenditure treasurers and treasurers of goods at 48 OPDs. The results of research based on Partial Least Square (PLS) show that user satisfaction affects the development of information systems, which will increase productivity, efficiency, and accuracy in using the system. In addition, the variable of accounting system complexity also affects the development of information systems, which will improve employee performance and production of accurate information.
\end{abstract}

Keyword: User Satisfaction, Accounting system complexity, Information System Development

\section{PENDAHULUAN}

Pesatnya perkembangan sistem informasi dan teknologi saat ini, membuat perkembangan di bidang sistem informasi sangat mempengaruhi kinerja perusahaan atau instansi secara keseluruhan. Informasi merupakan output dari suatu sistem informasi. Guna memperoleh informasi, maka diperlukan data karena merupakan input dari suatu sistem. Data diperoleh dari transaksi atau kegiatan yang terjadi dalam perusahaan. Sistem informasi semakin dibutuhkan, baik untuk membantu manajemen dalam menjalankan fungsinya maupun untuk kelangsungan perusahaan itu sendiri. 
Berdasarkan Peraturan Menteri Keuangan Republik Indonesia Nomor 213/PMK.05/2013 tentang sistem akuntansi dan pelaporan keuangan pemerintah berbasis akrual sebagaimana diamanatkan dalam Pasal 36 ayat (1) Undang-Undang Nomor 17 Tahun 2003 tentang Keuangan Negara dan Pasal 70 ayat (2) Undang-Undang Nomor 1 Tahun 2004 tentang Perbendaharaan Negara, perlu mengatur kembali ketentuan mengenai sistem akuntansi dan pelaporan keuangan Pemerintah. Pengembangan system informasi tersebut tidak terlepas dari kelengkapan teknologi informasi yang menjadi awal dari kelengkapan sistem teknologi informasi yang dimaksud juga dapat memberikan motivasi kerja dari setiap individu untuk melakukan tugas fungsionalnya. Salah satu aspek penting dalam pengembangan teknologi informasi ini adalah pengembangan system komputer sebagai basis kerja pemerintahan. Komputer merupakan solusi yang tepat bagi setiap perusahaan sebagai kelengkapan sistem informasi guna menunjang setiap keputusan yang ada (Jogiyanto, 2000: 53).

Pada kenyataannya, pengembangan sistem informasi memerlukan perencanaan dan implementasi yang hati-hati untuk menghindari adanya penolakan terhadap sistem yang dikembangkan (resistance to change). Untuk menghindari adanya penolakan terhadap sistem yang dikembangkan (resistance to change), maka diperlukan adanya partisipasi dari pemakai (Lau, 2003: 866). Pengembangan sistem informasi akan membawa pengaruh yang baik terhadap organisasi, tentunya berkomunikasi dengan para pemakai, oleh karena itu perlu mengidentifikasi kebutuhan sistem. Pengembangan sistem informasi saat ini sudah berkembang pesat dengan dibuatnya berbagai macam bentuk aplikasi untuk membantu menyelesaikan tugas pegawai agar waktu yang dibutuhkan lebih efektif dan lebih efisien. Sistem dikatakan efektif apabila sistem mampu menghasilkan informasi yang dapat diterima dan mampu memenuhi harapan informasi yang secara tepat waktu, akurat, dan dapat dipercaya.

Departemen Dalam Negeri telah mengeluarkan Peraturan Menteri Dalam Negeri (Permendagri) Nomor 13 tahun 2006 tentang Pedoman Pengelolaan Keuangan Daerah. Permendagri tersebut menjelaskan siklus keuangan daerah mulai dari tahapan perencanaan, penganggaran, penatausahaan, serta akuntansi dan pertanggungjawaban keuangan daerah. Selain itu juga disajikan sistem dan prosedur keuangan daerah beserta contoh-contoh formulir yang bisa digunakan oleh pemda baik secara manual maupun terkomputerisasi (computerized) Penyajian laporan keuangan dalam permendagri ini telah sesuai dengan Peraturan Pemerintah Nomor 24 tahun 2005 tentang Standar Akuntansi Pemerintahan (SAP).

BPKP dalam hal ini Deputi Pengawasan Bidang Penyelenggaraan Keuangan Daerah memberikan respon positif atas terbitnya permendagri ini, dengan menyusun suatu program aplikasi yang dapat digunakan oleh pemda dalam rangka pengelolaan keuangan daerahnya. Program aplikasi dimaksud adalah Program Aplikasi Komputer SIMDA. Program aplikasi ini telah diperkenalkan pada tanggal 29 Agustus 2006 oleh Deputi Pengawasan Bidang Penyelenggaraan Keuangan Daerah dengan versi pertama yaitu Versi 2.0. Hasil produk SIMDA versi pertama ini yaitu SIMDA keuangan, SIMDA BMD, SIMDA gaji, SIMDA pendapatan.

Program aplikasi komputer SIMDA Versi 2.1 ini dimaksudkan untuk membantu pengelolaan keuangan daerah baik di tingkat SKPKD (sebagai entitas pelaporan) maupun di tingkat SKPD (entitas akuntansi). Adanya program aplikasi ini diharapkan bisa memberikan manfaat lebih kepada pemda terutama dalam penyusunan APBD. Sesuai dengan visi BPKP sebagai Auditor Presiden yang responsif, interaktif dan terpercaya untuk mewujudkan akuntabilitas keuangan negara yang berkualitas dalam mentransformasikan manajemen pemerintahan menuju pemerintahan yang baik dan bersih serta sesuai amanat PP 60 tahun 2008 pasal 59 ayat (2) dan Inpres Nomor 4 Tahun 2011. 
Ada berbagai macam program aplikasi pada SIMDA yaitu yang pertama program aplikasi SIMDA keuangan versi 2.7.0.6 digunakan untuk pengelolaan keuangan daerah secara terintegrasi meliputi penganggaran, penatausahaan, akuntansi dan pelaporanya. Kedua program aplikasi SIMDA BMD versi 2.69 dan versi 2.0.69 program aplikasi ini digunakan untuk pengelolaan barang daerah meliputi perencanaan, pengadaan, penghapusan dan akuntansi barang daerah. Ketiga program apliksi SIMDA gaji dikembangkan berdasarkan kebutuhn pemerintah daerah dalam pengelolaan penggajian pegawainya. Keempat Program aplikasi komputer SIMDA pendapatan versi 1.2.0.9 tujuan pengembangan aplikasi ini adalah sebagai sarana optimalisasi pajak atau retrebusi daerah mengenai peloporan pendapatan dan piutang sebagai dokumen pendukung laporan pemerintah daerah yang dapat di andalkan. Output dari aplikasi SIMDA pendapatan yaitu pendataan, penetapan, dan penatausahaan. Pada tahun 2019 OPD sudah menggunakan SIMDA versi 27.013 maksudnya ini adalah versi ke 27 realis ke 13 untuk lebih memudahkan pegawai agar memberikan informasi yang dapat dierima dan mampu dipahami.

Dalam tabel 1.1 menjelaskan bahwa ada beberapa macam hasil produk pengembangan SIMDA. Aplikasi SIMDA dapat dimplemetasikan untuk pengelolaan keuangan daerah secara terintegrasi, menggunakan teknologi multi user dan teknologi client/server, dari penyusunan anggaran, pelaksanaan anggaran, dan pertanggungjawaban keuangan baik.

Tabel 1.1

Hasil Produk Pengembangan SIMDA

\begin{tabular}{|c|l|}
\hline 1. & Program Aplikasi SIMDA Keuangan \\
\hline 2. & $\begin{array}{l}\text { Program Aplikasi SIMDA Barang Milik Daerah } \\
\text { (BMD) }\end{array}$ \\
\hline 3. & Program Aplikasi SIMDA Gaji \\
\hline 4. & Program Aplikasi SIMDA Pendapatan \\
\hline 5. & Sub Aplikasi Display SPP s.d SP2D \\
\hline 6. & Sub Aplikasi Gabungan per Provinsi \\
\hline 7. & Sub Aplikasi Rekonsiliasi Bank \\
\hline
\end{tabular}

(Sumber:http://www.bpkp.go.id/sakd/konten/333/versi-2.1.bpkp)

Pengembangan sistem informasi atau SIMDA ini akan di update oleh BPKAD selanjutnya akan dioperasikan oleh Operasi Perangkat Daerah. Sistem dikatakan efektif apabila sistem mampu menghasilkan informasi yang dapat diterima dan mampu memenuhi harapan informasi yang secara tepat waktu, akurat, dan dapat dipercaya.

Berbagai penelitian tentang pengembangan sistem informasi sudah banyak dilakukan di Indonesia. Faktor-faktor pengembangan sistem informasi adalah kompleksitas sistem, kompleksitas tugas, partisipasi pemakai, komunikasi pemakai, latar belakang eksekutif, pengetahuan manajer, partisipasi manajemen, kinerja sistem, kecanggihan teknologi dan budaya organisasi. Namun penelitian ini berfokus pada faktor-faktor yang mempengaruhi pengembangan sistem informasi yang terdiri dari kepuasan pemakai dan kompleksitas sistem akuntansi.

Dua faktor di atas dipilih dengan alasan pertama, Kedua variabel tersebut untuk pengembangan sistem informasi sudah banyak diteliti, sehingga peneliti ingin menguatkan kembali hasil penelitian. Kedua, OPD sudah banyak menerapkan SIMDA sebagai bentuk pengembangan sistem informasi. Ketiga, adanya keterkaitan yang kuat antara partisipasi eksekutif, kepuasan pemakai dan kompleksitas sistem dengan pengembangan sistem informasi. 
Faktor pertama yang mempengaruhi pengembangan sistem informasi adalah kepuasan pemakai. Kepuasan pemakai sistem informasi adalah satu dari ukuran kunci yang dikembangkan awal tahun 1990 dalam menilai kesuksesan sebuah sistem. Hal ini sejalan dengan penelitian Ulfa (2020), Putri (2015), dan Christin (2017) yang menyatakan kepuasan pemakai berpengaruh terhadap pengembangan sistem informasi.

Faktor kedua yang mempengaruhi pengembangan sistem informasi adalah kompleksitas sistem akuntansi. Sistem akuntansi keuangan daerah sebagai suatu sistem informasi yang dapat membantu dalam penyajian dan peningkatan kualitas laporan keuangan pemerintah. Jika kualitas sistem informasi berjalan dengan baik, maka semua proses akan berjalan dengan lancar. Penyusunan laporan keuangan mulai dari pencatatan jurnal, buku besar sampai kepada laporan keuangan semua telah tersistem dengan menggunakan komputerisasi dan akan mengurangi tingkat kesalahan dalam perhitungan dan menghemat waktu dalam proses penyusunannya dirancang dalam kompleksitas sistem. Hal ini sejalan dengan penelitian Purnomo (2010), Ulfa (2020), Ratnaningsih (2014), Widyaningrum (2014), Rilly (2015).

Berdasarkan hal-hal yang terjadi pada pengembangan sistem informasi Operasi Perangkat Daerah Pemerintahan Provinsi Nusa Tenggara Barat, peneliti tertarik untuk melakukan penelitian pengembangan sistem informasi pemerintahan dengan variable kepuasan pemakai, kompleksitas sistem akuntansi dan pengembangan sistem informasi. Oleh karena itu peneliti tertarik melakukan penelitian dengan judul "Pengaruh Kepuasan Pemakai dan Kompleksitas Sistem Akuntansi terhadap Pengembangan Sistem Informasi".

\section{TINJAUAN PUSTAKA}

\section{Pengembangan Sistem Informasi}

\section{Pengertian Sistem Informasi}

Nash dan Roberts (Jogiyanto, 2000: 35) menyatakan bahwa "sistem informasi adalah suatu kombinasi dari orang-orang, fasilitas, teknologi, media, prosedur-prosedur dan pengendalian yang ditujukan untuk mendapatkan jalur komunikasi penting, memproses tipe transaksi rutin tertentu, memberi sinyal kepada manajemen dan yang lainnya terhadap kejadian-kejadian internal dan eksternal yang penting dan menyediakan suatu dasar untuk pengambilan keputusan yang cerdik". Menurut Puspitawati dan Anggadini (2011:64) sistem informasi adalah suatu sistem di dalam suatu organisasi yang mempertemukan kebutuhan pengolahan transaksi harian, mendukung kegiatan operasi sehari-hari dan menyediakan pihak-pihak tertentu dengan laporan-laporan yang diperlukan. Lucas (Jogiyanto, 2000: 35), menyatakan "sistem informasi adalah suatu kegiatan dari prosedur-proedur yang diorganisasikan bilamana dieksekusi akan menyediakan informasi untuk mendukung pengambil keputusan dan pengendalian di dalam organisasi”.

Terdapat empat atribut yang harus dipertimbangkan untuk menghasilkan informasi yang lebih baik, yaitu kecermatan, penyajian yang tepat waktu (relevan), lengkap dan ringkas. Tujuan dari pengembangan sistem informasi sangat terkait dengan empat atribut tersebut yaitu (Widjajanto, 2001: 518):

1. Sistem yang dihasilkan harus dapat menghasilkan informasi yang cermat dan tepat waktu.

2. Pengembangan sistem harus dapat diselesaikan dalam jangka waktu yang layak.

3. Sistem harus memenuhi kebutuhan informasi organisasi.

4. Sistem harus dapat memberikan kepuasan kepada penggunaannya. 


\section{Kepuasan Pemakai}

Harapan pemakai sistem informasi menentukan kepuasaan penggunaan sistem informasi. Oleh karena itu penting bagi pengembang sistem informasiuntuk mengetahui harapan para pemakai sistem informasi sehingga pada akhirnya mereka akan mencapai kepuasan dalam menggunakan sistem informasi. Untuk itu maka para pemakai hendaknya dilibatkan dalam pengembangan sistem. Kepuasan pemakai terhadap sistem informasi diharapkan dapat meningkatkan efektivitas sistem informasi.

Pengguna sistem informasi lebih dipengaruhi oleh staf sistem informasi dan pihak internal organisasi dibandingkan dengan pihak eksternal organisasi. Kepuasan pemakai sangat penting untuk meningkatkan produktivitas, efisiensi, dan ketelitian pembuatan laporan organisasi. Efektivitas sistem informasi organisasi secara positif dihubungkan dengan kepuasan pemakai.

Literatur-literatur yang ada menyatakan bahwa tolok ukur efektivitas sistem informasi dapat dilihat dari kepuasan pemakainya. Kepuasan pengguna merupakan perasaan bersih dari senang atau tidak senang dalam menerima sistem informasi dari keseluruhan manfaat yang diharapkan seseorang dimana perasaan tersebut dihasilkan dari interaksi dengan sistem informasi.

Kepuasan pemakai sistem informasi digunakan untuk mengukur tingkat kepuasan pemakai system informasi terhadap sistem dan output yang dihasilkan. Variable kpuasan pemakai diukur dengan indikator DeLone dan McLean (2003) yang terdiri dari :

1. Kepuasan informasi (information satisfaction). Secara umum kepuasan informasi merupakan hasil perbandingan antara harapan atau kebutuhan sistem informasi dengan kinerja sistem yang diterima.

2. Kepuasan menyeluruh (overall satisfaction). Kepuasan menyeluruh merupakan salah satu kepuasan secara global atas semua sistem yang sudah disajikan dan dilakukan interaksi mengenai tingkat kepuasan layanan informasi dan sistem, serta manfaat dalam proses input maupun proses output yang diterima.

\section{Kompleksitas Sistem Informasi Akuntansi}

Sistem informasi akuntansi adalah kumpulan sumber daya, seperti manusia dan peralatan yang dirancang untuk mengubah data keuangan dan data lainnya ke dalam informasi. Informasi tersebut dikomunikasikan kepada para pembuat keputusan. Sistem informasi akuntansi melakukan hal tersebut dengan system manual atau melalui sistem terkomputerisasi (Bodnar dan Hopwood: 3). Sistem informasi akuntansi merupakan sistem informasi yang fungsional yang mendasari sistem fungsional lainnya seperti sistem keuangan, sistem informasi pemasaran, sistem informasi produksi, dan sistem informasi sumber daya manusia.

Sistem informasi akuntansi pelaksanaan aktivitas tugas-tugas akuntansi yang dilakukan pada perusahaan, terbagi atas beberapa subsistem dari system informasi akuntansi yaitu:

a. Sistem Pemrosesan Transaksi

b. Sistem Buku Besar atau Pelaporan Keuangan

c. Sistem Pelaporan Manajemen

Dari penjelasan di atas dapat disimpulkan bahwa sistem informasi akuntansi dibuat untuk memberikan informasi keuangan yang dibutuhkan oleh manajemen sebuah perusahaan guna memudahkan pengelolaan perusahaan. 


\section{Komponen Sistem Akuntansi Pemerintah}

1. Program Aplikasi SIMDA Keuangan Versi 2.7.0.6 Program aplikasi ini digunakan untuk pengelolaan keuangan daerah secara terintegrasi, meliputi penganggaran, penatausahaan, akuntansi dan pelaporannya. Output aplikasi ini antara lain:

a. Penganggaran

Rencana Kerja Anggaran (RKA), RAPBD dan Rancangan Penjabaran APBD, APBD dan Penjabaran APBD beserta perubahannya, Dokumen Pelaksanaan Anggaran (DPA).

b. Penatausahaan

Surat Penyediaan Dana (SPD), Surat Permintaan Pembayaran (SPP), Surat Perintah Membayar (SPM), SPJ, Surat Perintah Pencairan Dana (SP2D), Surat Tanda Setoran (STS), beserta register-register, dan formulir-formulir pengendalian anggaran lainya.

c. Akuntansi dan Pelaporan

Jurnal, Buku Besar, Buku Pembantu, Laporan Keuangan (Laporan Realisasi Anggaran, Laporan Arus Kas dan Neraca), Perda Pertanggungjawaban dan Penjabarannya.

2. Program Aplikasi SIMDA BMD Versi 2.69 dan Versi 2.0.69. Program aplikasi ini digunakan untuk pengelolaan barang daerah meliputi perencanaan, pengadaan, penatausahaan, penghapusan dan akuntansi barang daerah. Output aplikasi ini antara lain:

a. Perencanaan

Daftar Kebutuhan Barang dan Pemeliharaan, Daftar Rencana Pengadaan Barang Daerah dan Daftar Rencana Pemeliharaan Barang Daerah.

b. Pengadaan

Daftar Hasil Pengadaan, Daftar Hasil Pemeliharan Barang, dan Daftar Kontrak Pengadaan.

c. Penatausahaan

Kartu Inventaris Barang (KIB), Kartu (sejarah) Barang, Kartu Inventaris ruangan (KIR), Buku Inventaris (BI), Daftar Mutasi Barang Daerah, dan Rekap Hasil Sensus, serta Label Barang.

d. Penghapusan

SK Penghapusan, Lampiran SK Penghapusan dan Daftar Barang yang dihapuskan.

e. Akuntansi

Daftar Barang yang masuk Neraca (Intracomptable), Daftar Barang Extra Comptable, Lampiran Neraca, Daftar Penyusutan Aset Tetap, dan Daftar Aset Lainnya (Barang Rusak Berat), serta Rekapitulasi Barang Per OPD. Aplikasi SIMDA BMD dikembangkan dalam dua basis, yaitu berbasis dekstop dan berbasis Web serta dapat dikoneksikan dengan GIS.

3. Program Aplikasi Komputer SIMDA Gaji

Aplikasi Komputer SIMDA Gaji dikembangkan berdasarkan kebutuhan pemerintah daerah dalam pengelolaan penggajian pegawainya. Aplikasi ini akan membantu pemda untuk memproses penggajian secara lebih cepat, akurat serta menghasilkan dokumen penggajian yang dapat diandalkan. Ouput dari aplikasi adalah sebagai berikut:

a. Daftar Gaji, Rapel, Gaji Terusan, Perhitungan Pajak.

b. Daftar Pegawai.

c. Register- register.

4. Program Aplikasi Komputer SIMDA Pendapatan Versi 1.2.0.9

Tujuan pengembangan aplikasi ini adalah sebagai sarana optimalisasi pajak/retribusi daerah serta agar pemerintah daerah dapat menghasilkan laporan-laporan 
pengelolaan pendapatan dan piutang sebagai dokumen pendukung laporan keuangan pemerintah daerah yang dapat diandalkan. Ouput dari aplikasi antara lain sebagai berikut:

a. Pendataan

Formulir Pendaftaran, Tanda Terima Pendaftaran, Kartu NPWP/RD, Daftar Wajib Pajak/Retribusi, Daftar SPTP/RD, dan Kartu Data.

b. Penetapan

Nota Perhitungan Pajak/Retribusi Daerah, SKP/RD (Surat Ketetapan Pajak/Retribusi Daerah), Daftar SPKP/RD, SKP/RD Tambahan, SKPD/R Kurang Bayar, SKP/RD Nihil, Daftar Surat Ketetapan Pajak/Retribusi Daerah dan Daftar Tunggakan Pajak/Retribusi Daerah.

c. Penatausahaan

Laporan Penerimaan Harian, Laporan Realisasi Penerimaan, Kartu Piutang, Buku Pembantu Rincian Penerimaan per Obyek, STS (Surat Tanda Setoran) dan Buku Kas Umum.

Seluruh program aplikasi SIMDA didukung dengan :

1. Buku Manual Sistem dan Prosedur sesuai dengan jenis aplikasi

2. Buku Pedoman Pengoperasian Aplikasi

3. Panduan-panduan Pembantu lainnya, misalnya Pedoman Penyusunan Laporan Keuangan, Modul Pengelolaan Barang Milik Daerah, Modul Substansi Pengelolaan Gaji PNS Daerah, dan Panduan Administrator.

Indikator kompleksitas sistem akuntansi dalam penelitian ini mengacu pada DeLone and McLean (2003) antara lain :

1. Kualitas informasi, mengukur kualitas keluaran dari sistem informasi.

DeLone dan McLean (1992), melihat kualitas informasi dari tingkat akurasi, ketepatan, kelengkapan, ketepat waktuan, bentuk dan relevansi dari informasi yang dihasilkan.

2. Kualitas sistem, performa dari sistem yang merujuk pada seberapa baik kemampuan perangkat keras, perangkat lunak, kebijakan, prosedur dari sistem informasi dapat menyediakan informasi kebutuhan pengguna.

3. Kualitas pelayanan, seberapa jauh perbedaan antara kenyataan dan harapan para pelanggan atas pelayanan yang mereka terima atau peroleh.

4. Kepuasan pengguna, pengungkapan kesesuaian antara harapan seseorang dengan hasil yang diperolehnya, dikarenakan adanya partisipasi selama pengembangan sistem. kepuasan pengguna sistem informasi digunakan untuk mengukur tingkat kepuasan pemakai sistem informasi terhadap system dan output yang dihasilkan.

5. Penggunaan sistem, penyelesaian tugas tepat pada waktunya sesuai dengan rencana yang sudah ditetapkan yang menunjukkan tingkat keberhasilan atau kegagalan kegiatan manajemen dalam mencapai tujuan.

\section{METODOLOGI}

Penelitian ini menggunakan metode penelitian asosiatif, di mana Penelitian ini dilakukan di OPD Provinsi Nusa Tenggara Barat, karena setiap OPD akan memperbaharui SIMDA dengan versi yang berbeda-beda agar menghasilkan informasi yang tepat waktu, akurat dan dapat dipercaya. Dengan adanya pengembangan kemampuan sistem versi yang lama ke kemampuan system versi yang baru dapat memberi peningkatan pada sistem. Selain itu adanya kemudahan dalam mengakses data juga menjadi salah satu pertimbangan peneliti untuk mengambil lokasi di OPD PemProv NTB.

\section{Populasi dan Sampel}


Menurut Sugiyono (2016: 80), populasi adalah wilayah generalisasi yang terdiri atas obyek atau subyek yang mempunyai kualitas dan karakteristik tertentu yang ditetapkan oleh peneliti untuk dipelajari dan kemudian ditarik kesimpulan. Populasi yang digunakan dalam penelitian ini adalah seluruh pegawai OPD yang berada di Pemerintahan Provinsi NTB. Menurut Sugiyono (2016: 217), sampel adalah bagian dari jumlah dan karakteristik yang dimiliki oleh populasi tersebut. Apa yang dipelajari dari sampel itu, kesimpulannya akan dapat diberlakukan untuk populasi. Sampel dari penelitian ini menggunakan metode noprobability dengan teknik purposive sampling. Purposive sampling adalah metode penetapan responden dengan kriteria tertentu yang telah ditentukan.

Tabel 3.1. Kriteria Sampel

\begin{tabular}{|l|l|}
\hline Kriteria & Jumlah \\
\hline Seluruh pegawai OPD di Pemprov NTB & $\mathbf{1 4 . 3 8 9}$ \\
\hline $\begin{array}{l}\text { Pegawai yang tidak melaksanakan atau memegang sistem } \\
\text { akuntansi dan } \\
\text { tata kelola keuangan }\end{array}$ & $\mathbf{( 1 4 . 2 9 3 )}$ \\
\hline Sampel Penelitian & $\mathbf{9 6}$ \\
\hline
\end{tabular}

Sumber :https://bkd.ntbprov.go.id/informasi-umum/statistik-pegawai

\section{Jenis dan Sumber Data}

Jenis data yang digunakan dalam penelitian ini adalah data kuantitatif. Data kuantitatif adalah data yang berbentuk angka, mulai dari pengumpulan data, penafsiran terhadap data, serta hasilnya berbentuk angka (Sugiono 2016:8).

Sumber data dalam penelitian ini adalah data primer. Di dalam penelitian ini data primer diperoleh melalui kuisioner kepada responden yang ada di OPD Provinsi NTB. Kuisioner yang di sebar berisi pertanyaan mengenai kompleksitas sistem akuntansi terhadap pengembangan sistem informasi. Dalam penelitian ini pengukuran masing-masing indikator menggunakan skala likert.

\section{Teknik pengumpulan Data}

Teknik pengumpulan data yang digunakan dalam penelitian ini adalah kuesioner. Kuesioner merupakan teknik pengumpulan data yang dilakukan dengan cara memberi seperangkat pertanyaan atau pernyataan tertulis secara terstruktur kepada responden penelitian berkaitan dengan tanggapannya terhadap berbagai variabel yang diteliti dalam penelitian ini (Sugiyono, 2016: 142).

\section{Variabel Penelitian}

Berdasarkan pokok permasalahan dan hipotesis yang telah dirumuskan, maka variabel-variabel yang dianalisis dalam penelitian ini adalah:

1. Variabel eksogen yaitu variabel yang menjadi sebab timbulnya atau berubahnya variabel endogen. Variabel eksogen dalam penelitian ini adalah kompleksitas sistem informasi akuntansi.

2. Variabel endogen yaitu variabel yang dipengaruhi atau menjadi akibat karena adanya eksogen. Variabel endogen dalam penelitian ini adalah pengembangan sistem informasi.

\section{Prosedur Analisis Data}

Analisis statistik asosiatif untuk menilai adanya hubungan antar variabel. Untuk menguji hipotesis digunakan teknik Partial Least Square (PLS) menggunakan aplikasi software Smart PLS 3.0. PLS merupakan analisis persamaan struktural berbasis varian yang 
secara simultan dapat melakukan pengujian model pengukuran sekaligus pengujian model struktural. Terdapat tujuh langkah yang harus dilalui dalam model PLS yaitu sebagai berikut:

1. Merancang model structural (inner model)

2. Meranancang model pengukuran (outer model)

3. Merekonstruksi diagram jalur

4. Konversi diagram jalur ke sistem persamaan

5. Estimasi koefisien jalur \& nilai loading

6. Evaluasi goodness of fit

7. Pengujian hipotesis

\section{HASIL DAN PEMBAHASAN}

Analisis Data

\section{Uji Validitas}

\section{Convergent Validity}

Convergent Validity dalam PLS dengan indikator reflektif dinilai berdasarkan loading factor (korelasi antara skor item/skor komponen dengan skor konstruk) indikator-indikator yang mengukur konstruk tersebut. Rule of thumb yang biasanya digunakan untuk mengukur validitas konvergen adalah outer loading > 0,7, namun menurut Chin (1998) nilai loading factor 0,5 sd 0,6 masih dianggap cukup (Ghozali, 2015;74). Nilai loading factor dalam penelitian ini ditunjukkan dalam tabel 4.7 sebagai berikut:

Tabel 4.1. Loading Factor

\begin{tabular}{|c|c|c|c|c|}
\hline & KSA & KP & PSI & KETERANGAN \\
\hline $\mathrm{X} 1.1$ & 0.801 & & & VALID \\
\hline $\mathrm{X} 1.2$ & 0.87 & & & VALID \\
\hline $\mathrm{X} 1.3$ & 0.657 & & & VALID \\
\hline $\mathrm{X} 1.4$ & 0.652 & & & VALID \\
\hline $\mathrm{X} 1.5$ & 0.560 & & & VALID \\
\hline $\mathrm{X} 2.1$ & & 0.787 & & VALID \\
\hline $\mathrm{X} 2.2$ & & 0.882 & & VALID \\
\hline $\mathrm{Y} 1.1$ & & & 0.904 & VALID \\
\hline $\mathrm{Y} 1.2$ & & & 0.875 & VALID \\
\hline $\mathrm{Y} 1.3$ & & & 0.676 & VALID \\
\hline
\end{tabular}

Sumber: Data primer diolah 2020

Berdasarkan tabel 4.7 Loading Factor, sebagai kriteria pengujian convergen validity, terlihat dengan jelas indikator-indikator diatas memiliki nilai diatas 0,5 sehingga tidak perlu dieliminasi. Dapat dilihat model struktural pada penelitian ini ditampilkan pada gambar 4.1 berikut:

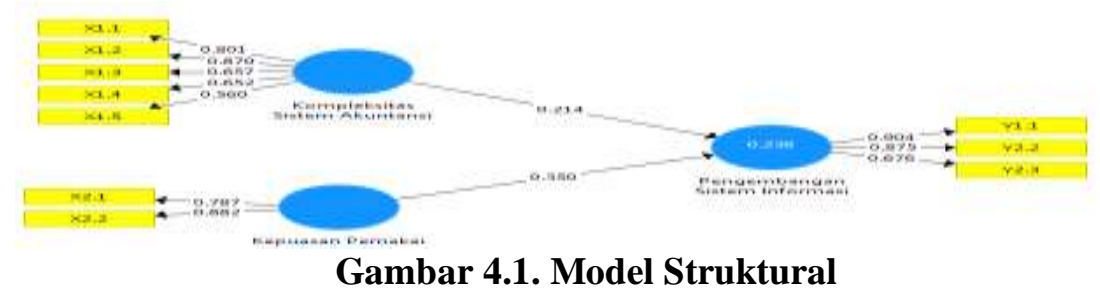




\section{Discriminant Validity}

Untuk discriminant validity setiap indikator diuji dengan cross loading, pada tabel 4.2, pengujian discriminant validity digunakan untuk melihat bahwa masing-masing indikator di suatu konstruk akan berbeda dengan indikator di konstruk lain dan mengumpul pada konstruk yang dimaksud.

Tabel 4.2. Cross Loading

\begin{tabular}{|l||c||c||c|}
\hline \hline Xompleksitas Sistem & $\begin{array}{c}\text { Kepuasan } \\
\text { Pemakai }\end{array}$ & Pengembangan SistemInformasi \\
\hline \hline X1.1 & 0.800669 & 0.231128 & 0.238758 \\
\hline $\mathbf{X 1 . 2}$ & 0.870331 & 0.306233 & 0.414179 \\
\hline X1.3 & 0.657437 & 0.462628 & 0.216512 \\
\hline X1.5 & 0.651732 & 0.296398 & 0.178245 \\
\hline X2.1 & 0.560231 & 0.467059 & 0.202001 \\
\hline \hline X2.2 & 0.313601 & 0.787118 & 0.321771 \\
\hline \hline Y1.1 & 0.373526 & 0.881714 & 0.420679 \\
\hline \hline Y2.2 & 0.284016 & 0.499676 & 0.904121 \\
\hline Y2.3 & 0.254274 & 0.343686 & 0.875261 \\
\hline Sumb & 0.176078 & 0.675566 \\
\hline
\end{tabular}

\section{Sumber: Data primer diolah 2020}

Berdasarkan pada tabel 4.2 dapat dilihat bahwa semua indikator memiliki nilai diatas 0,5 sehingga indikator-indikator tersebut dapat diolah lebih lanjut, dan dapat disimpulkan bahwa konstruk telah memiliki convergent validity yang baik. Nilai cross loading juga menunjukkan adanya discriminant validity yang baik oleh karena nilai korelasi lebih tinggi dibandingkan dengan konstruk lainnya. Sebagai ilustrasi loading factor X1.1 sebesar 0,800 lebih tinggi dibandingkan dengan kepuasan pemakai $(0,231)$ dan Pengembangan Sistem Informasi $(0,238)$.

\section{Uji Realibilitas}

Uji reliabilitas dapat dilihat dari nilai composive reliability dan cronbach's alpha. Untuk dapat dikatakan suatu konstruk yang reliabel, maka nilai cronbach's alpha harus $>0,6$ dan nilai composive reliability harus $>0,7$. Berikut adalah hasil pengujian untuk composive reliability dan cronbach's alpha.

Tabel 4.3. Composite Realibility

\begin{tabular}{|c|c|}
\hline & Composite Reliability \\
\hline \hline KepuasanPemakai & 0.837581 \\
\hline KompleksitasSistem & 0.822013 \\
\hline PengembanganSistemInformasi & 0.862586 \\
\hline
\end{tabular}

Sumber: Data Primer diolah 2020 
Berdasarkan tabel 4.9 dapat diketahui bahwa semua konstruk dinyatakan reliable karena semua konstruk memiliki nilai diatas 0,70. Sehingga dapat dikatakan bahwa konstruk pada penelitian ini memiliki reliabilitas yang baik.

Tabel 4.4. Cronbach Alpha

\begin{tabular}{|c||c|}
\hline & Cronbachs Alpha \\
\hline \hline KepuasanPemakai & 0.764262 \\
\hline \hline Kompleksitas Sistem & 0.744991 \\
\hline PengembanganSistemInformasi & 0.772313 \\
\hline
\end{tabular}

Sumber: Data Primer diolah 2020

Berdasarkan tabel 4.4 dapat diketahui bahwa nilai Cronbach's Alpha untuk semua konstruk sudah berada diatas 0,7 . Sehingga dapat dikatakan bahwa konstruk pada penelitian ini memiliki reliabilitas yang baik.

\section{Uji Hipotesis}

Uji hipotesis dilakukan untuk menjawab masalah penelitian yang telah dirumuskan sebelumnya dengan menggunakan software SmartPLS. Langkah selanjutnya setelah dilakukan uji convergent validity dan discriminant validity, yaitu melakukan pengujian model struktural (inner model). Nilai structural dapat dilihat melalui hasil estimasi koefisien parameter path dan tingkat signifikannya. Nilai $R$-square dapat dilihat pada tabel 4.5 dibawah ini:

Tabel 4.5. R-Square

\begin{tabular}{|l|l|}
\hline \hline & R Square \\
\hline PengembanganSistemInformasi & 0.237935 \\
\hline
\end{tabular}

Sumber: Data Primer diolah 2020

Berdasarkan tabel 4.5 menunjukkan nilai $R$-square untuk pengembangan sistem informasi sebesar 0,237 yang dapat diinterpretasikan bahwa pengembangan sistem informasi dapat dijelaskan oleh variabel konstruk kepuasan pemakai dan kompleksitas sistem akuntansi sebesar $23,7 \%$, sedangkan sisanya 76,3\% dijelaskan oleh variabel diluar yang diteliti seperti kompleksitas sistem, kompleksitas tugas, komunikasi pemakai, latar belakang eksekuif, kecanggihan teknologi dan budaya organisasi.

Selanjutnya dilakukan $Q$-square test yang digunakan untuk mengevaluasi predictive relevance. Nilai $Q$-square lebih besar dari 0 (nol) meunjukkan bahwa model mempunyai predictive relevance, sedangkan nilai $Q$-square kurang dari 0 (nol) menunjukkan bahwa kurang memiliki predictive relevance. Nilai $Q$-square didapatkan dengan memasukkan nilai $R$-square kedalam rumus $Q$-square berikut:

$\mathrm{Q}^{2}=1-\left(1-\mathrm{R}^{2}\right)$

$=1-(1-0,237)$

$=0,237$

Berdasarkan hasil perhitungan yang dilakukan diperoleh nilai Q-square yang sama dengan nilai R-square, sehingga dapat dijelaskan bahwa variabel laten yang digunakan dalam model memiliki relevansi prediksi. Selanjutnya pengujian hipotesis dilakukan dengan uji $t$ untuk menguji apakah variabel eksogen berpengaruh signifikan terhadap variabel endogen. 
Dalam menguji hipotesis, dasar yang diguanakan terdapat pada output result for inner weight berikut:

Tabel 4.6. Result For Inner Weight

Path Coefficient (Mean, STDEV, T-Values)

\begin{tabular}{|c|c|c|c|c|c|c|c|}
\hline & $\begin{array}{c}\text { Original } \\
\text { Sample (O) }\end{array}$ & $\begin{array}{c}\text { Sample } \\
\text { Mean (M) }\end{array}$ & $\begin{array}{l}\text { Standard } \\
\text { Deviation } \\
\text { (STDEV) }\end{array}$ & $\begin{array}{l}\text { T Statistics } \\
(|\mathrm{O} / \mathrm{STERR}|)\end{array}$ & T- Table & $\mathbf{H}$ & Keterangan \\
\hline KP ->PSI & 0.214260 & 0.247622 & 0.115361 & 1.857301 & 1,66 & 1 & Diterima \\
\hline KS ->PSI & 0.349759 & 0.356043 & 0.110764 & 3.157701 & 1,66 & 2 & Diterima \\
\hline
\end{tabular}

Sumber: Data Primer diolah 2020

Berdasarkan tabel 4.6 dapat terlihat bahwa:

1. Variabel kepuasan pemakai memiliki koefisien 0,247 dan nilai T-statistic 1,857 > 1,66 (T-tabel) dengan signifikan 5\% (lima) persen (one tailed), artinya hipotesis diterima, sehingga penelitian ini menerima hipotesis pertama (H1), dimana kepuasan pemakai berpengaruh positif terhadap pengembangan sistem informasi OPD. Semakin tinggi tinggat kepuasan pemakai dalam menggunakan sistem yang dikembangkan maka akan meningkatkan kinerja dan akan memudahkan pemakai untuk bekerja secara efisien.

2. Variabel kompleksitas sistem akuntansi memiliki koefisien parameter 0,349 dan nilai Tstatistic 3,157 > 1,66 (T-tabel) dengan signifikan 5\% (lima) persen (one tailed), artinya hipotesis diterima, sehingga penelitian ini menerima hipotesis kedua $(\mathrm{H} 2)$, dimana kompleksitas sistem akuntansi berpengaruh positif terhadap pengembangan sistem informasi OPD. Semakin lengkap sistem yang dikembangkan maka akan menghasilkan informasi yang lebih akurat.

\section{Pembahasan}

\section{Pengaruh Kepuasan Pemakai Terhadap Pengembangan Sistem Informasi}

Kehadiran sistem informasi telah memberikan begitu banyak pengaruh terhadap suatu organisasi. Penentu kepuasan dari penguna adalah mutu dari system dan informasi sistem tersebut yang didasarkan pada kebutuhan dan harapan pengguna. Apabila kebutuhan dan harapan pengguna sudah terpenuhi serta mutu informasi dan sistem yang disediakan bernilai baik pada akhirnya akan mendukung kesuksesan system informasi tersebut dan memberikan dampak pada organisasi.

\section{Kesimpulan}

Sesuai dengan tujuan penelitian ini yaitu menguji dan menganalisis pengaruh Kepuasan Pemakai dan Kompleksitas Sistem Akuntansi terhadap Pengembangan Sistem Informasi. Pengujian dilakukan dengan menggunakan analisis Partial Least Square (PLS). Berdasarkan hasil penelitian yang dilakukan maka dapat diambil kesimpulan sebagai berikut :

1. Kepuasan pemakai berpengaruh terhadap pengembangan sistem informasi di Organisasi Perangkat Daerah Provinsi Nusa Tenggara Barat. Hal ini berarti, kepuasan pemakai dilihat dari pengembangan sistem informasi apakah sudah sesuai dengan kebutuhan pemakai untuk meningkatkan produktivitas, efisien, dan ketelitian dalam menggunakan sistem akuntansi.

2. Kompleksitas sistem akuntansi berpengaruh terhadap pengembangan sistem informasi di Organisasi Perangkat Daerah Provinsi Nusa Tenggara Barat. Hal ini berarti, jika 
kompleksitas sistem akuntansi dari pengembangan sistem sudah dapat diterima oleh pengguna sistem tersebut maka akan meningkatkan kinerja pegawai dan menghasilkan informasi yang relevan.

\section{DAFTAR PUSTAKA}

Bodnar, George H. dan William S. Hopwood. 2001. Sistem Informasi Akuntansi. Jakarta: Salemba Empat.

Chin, W. W. (1998).The Partial Least Squares Aproach to Structural EquationModeling. Modern Methods for Business Research,295, 336

Chistian, Made, dkk. 2017. Pengaruh Kecanggihan Teknologi Informasi, Partisipasi Manajemen, Budaya Organisasi, dan Kepuasan Pengguna pada Efektivitas Sistem Informasi Akuntansi Bank Perkreditan Rakyat di Kabupaten Buleleng.

DeLone, W. H. dan E.R Mclean. 1992. Information System Success: The Quest for the Dependent Variable, Information System Research, 3(1): 60-95. 2003.

Ghozali, Imam, 2015, Structural Equation Modeling Metode Alternatif dengan Partial Least Square (PLS). Semarang: Badan Penerbit Universitas Diponegoro.

Jogiyanto, H.M. 2000. Sistem Informasi Akuntansi Berbasis Komputer Edisi 2. Yogyakarta: BPFE.

Lau, Efreda Aplonia. 2003. Pengaruh Partisipasi Pemakai Terhadap Kepuasan Pemakai dalam Pengembangan Sistem Informasi dengan Lima Variabel Moderating. Simposium Nasional Akuntansi VI, hal. 866-882.

Peraturan Pemerintah Nomor 71 Tahun 2010, tentang Standar Akuntansi Pemerintahan, Jakarta.

Purnomo, Tedi. 2010. Pengaruh Dukungan Manajemen Puncak dan Pengetahuan Manajer terhadap Efektivitas Sistem Informasi Akuntansi.

Putri, Agustina Harlina. 2015. Pengaruh Dukungan Manajemen Puncak dan Komunikasi Pemakai-Pengembang terhadap Hubungan Partisipasi dan Kepuasan Pemakai dalam Pengembangan Sistem Informasi (Studi Empiris di DKI Jakarta). Other Thesis, Unika Soegijapranata.

Ratnaningsih, dkk. 2014. Pengaruh Kecanggihan Teknologi Informasi, Partisipasi Manajemen dan Pengetahuan Manajer Akuntansi pada Efektifitas Sistem Informasi Akuntansi.

Rilly, Kadek. 2015. Faktor-Faktor yang Berpengeruh Terhadap Kinerja Sistem Informasi Akuntansi pada Bank Perkreditan Rakyat di Kabupaten Buleleng.

Sugiyono, 2016, Metode Penelitian Kuantitatif Kualitatif dan R\&D. Bandung: ALFABETA.

Ulfa, Baiq Adriani. 2020. Pengaruh Partisipasi Eksekutif dan Kompleksitas Sistem terhadap Pengembangan Sistem pada Perusahaan Konstruksi di Kota Mataram

Widjajanto, Nugroho. 2001. Sistem Informasi Akuntansi. Erlangga: Jakarta

Widyaningrum, Vitra. 2014. Analisis Faktor-faktor yang Mempengaruhi Kinerja Sistem Informasi Akuntansi.

http://www.bpkp.go.id/sakd/konten/333/versi-2.1.bpkp di akses jam 14.29 WITA Tgl. 29-819. https://bkd.ntbprov.go.id/informasi-umum/statistik-pegawai www.bulungan.go.id diakses 5 Januari 2020. Selasa, 01.25 WITA. 